УДК 657.01

JEL classification: $M 41$

Панасюк Т.П.

ORCID ID 0000-0002-5073-7428

Маленко М.В.

ORCID ID 0000-0002-1759-2984

студентки 3 курсу ФММ

Лободзинська Т.П.

канд. економ. наук, доцент ORCID ID 0000-0001-5518-727X

Національний технічний університет України

"Київський політехнічний інститут імені Ігоря Сікорського"

\title{
ПОРІВНЯЛЬНИЙ АНАЛІЗ ФІНАНСОВИХ ЗВІТІВ КРАЇН СВІТУ ЗА МІЖНАРОДНИМИ ТА НАЦІОНАЛЬНИМИ СТАНДАРТАМИ
}

\section{СРАВНИТЕЛЬНЫЙ АНАЛИЗ ФИНАНСОВЫХ ОТЧЕТОВ СТРАН МИРА ПО МЕЖДУНАРОДНЫМ И НАЦИОНАЛЬНЫМ СТАНДАРТАМ}

\section{COMPARATIVE ANALYSIS OF THE WORLD FINANCIAL REPORTS BY INTERNATIONAL AND NATIONAL STANDARDS}

У статті проведено дослідження та визначено актуальність здійснення порівняльного аналізу фінансових звітів країн світу згідно вимог міжнародних стандартів фінансової звітності (МСФ3), загальноприйнятих принщипів обліку США (GAAP) та національного положення (стандарту) бухгалтерського обліку (НП(С)БО). Опрацьовано роботи вчених-економістів за суміжними дослідженнями. Проведено дослідження балансів різних країн світу та виявлено відмінності їх форми, структури і методики складання. Проаналізовано принщип розміщення статей у звітах про фінансовий стан підприємства, їх групування за рівнем ліквідності. Систематизовано дані за планами рахунків бухгалтерського обліку. Наведено перелік установ, щуо формують стандарти бухгалтерського обліку та фінансової звітності закордоном $i$ в Украӥні. Визначено особливості формування структури балансів за національними $i$ міжнародними стандартами. Здійснено порівняльний аналіз оцінки статей балансу згідно вимог МСФЗ та GAAP. Ідентифіковано розбіжності методики формування статей балансу згідно вимог НП(С)БО та МСФЗ. Зазначено, щзо запозичення закордонного досвіду облікової системи сприятиме створенню дієвого механізму для прийняття управлінських рішень, спрямованих на швидке орієнтування суб'єктів господарювання в системі сучасних інтеграційних процесів.

Ключові слова: національне положення (стандарт) бухгалтерського обліку, міжнародні стандарти фінансової звітності, загальноприйняті принципи обліку, бухгалтерський облік, баланс, вертикальна і горизонтальна форми балансу, ліквідність статей.

В статье проведено исследование и определена актуальность осуществления сравнительного анализа финансовых отчетов стран мира в соответствии с требованиями международных стандартов финансовой отчетности (МСФО), 
общепринятых принципов учета США (GAAP) и национального положения (стандарта) бухгалтерского учета (НП(С)БУ). Обработаны труды ученых-экономистов по смежным исследованиями. Проведено исследование балансов разных стран мира и выявлены различия их формы, структуры и методики составления. Проанализированы принципь размещения статей в отчетах о финансовом состоянии предприятия, их группировка по уровню ликвидности. Систематизированы данные по планам счетов бухгалтерского учета. Приведен перечень учреждений, формирующих стандарты бухгалтерского учета и финансовой отчетности за рубежсом и в Украине. Определены особенности формирования структуры балансов по национальным и международным стандартам. Осуществлен сравнительный анализ оценки статей баланса в соответствии с требованиями МСФО и GAAP. Идентифииированы разногласия методики формирования статей баланса в соответствии с требованиями НП(С)БУ и МСФО. Отмечено, что заимствование зарубежного опыта учетной системь будет способствовать созданию действенного механизма для принятия управленческих решений, направленных на быстрое ориентирование субъектов хозяйствования в системе современных интеграчионных проиессов.

Ключевые слова: национальное положение (стандарт) бухгалтерского учета, международные стандарты финансовой отчетности, общепринятые принципы учета, бухгалтерский учет, баланс, вертикальная и горизонтальная формы баланса, ликвидность статей.

In the article was carried out the research and identified the actuality of comparative analysis of the world financial reports according to requirements of International Financial Reporting Standards (IFRS), generally accepted accounting principles in US (GAAP) and national standards of accounting (NSA). It was processed works of economists by related research. It was investigated balances around the world and found differences in their form, structure and methods of assembly. It was analyzed the principle of placing items in the report of financial position, grouping them in terms of liquidity. It was systematized the data on the chart of accounts. It was given the list of institutions that form the accounting standards and financial reporting in Ukraine and abroad. It was determined the features of formation of structure balances by national and international standards. It was realized the comparative analysis of the evaluation of balance sheet under IFRS and GAAP. It was identified discrepancies in methods of forming balance sheet as required in NSA and IFRS. It was indicated that borrowing of foreign experience in the accounting system will help to create an effective mechanism for management decisions which will be directed to rapid targeting entities in the system of modern integrational processes.

Keywords: national standard of accounting, international financial reporting standards, generally accepted accounting principles, accounting, balance sheet, vertical and horizontal forms of balance sheet, liquidity items.

Вступ. В сучасному середовищі, 3 входженням національного господарства України в світовий економічний простір, постала необхідність адаптації національної системи бухгалтерського обліку до вимог міжнародної практики, що реалізується за міжнародними стандартами фінансової звітності (МСФ3) (International Financial Reporting Standards (IFRS)) та загальноприйнятими принципами обліку США Generally Accepted Accounting Principles (GAAP). 
Фінансовий стан, одна 3 найважливіших характеристик господарської діяльності підприємств, що має відображення у бухгалтерському балансі. Питання формування балансу стосується будь-якого підприємства, що здійснює господарську діяльність. Однак баланси різних країн мають низку відмінностей, які необхідно враховувати, наприклад, при організації бізнесу закордоном. Важливим $\epsilon$ i виділення відмінностей в балансах за національними i міжнародними стандартами, тому що в Україні мають застосування і перші, і другі. Дослідження змін, що відбулися в результаті переходу до національного положення (стандарту) бухгалтерського обліку (НП(С)БО) є надзвичайно актуальним на сучасному етапі.

Вивченню проблем та перспектив розвитку бухгалтерського обліку в умовах інтеграції присвячені праці вчених: Ф. Бутинця [9], С. Голова [10], М. Кужельного, С. Левицької [11], В. Сопка [12] та інших. Актуальні проблеми складання та подання балансу, дослідження відмінностей у фінансових звітах різних країн світу висвітлено у працях українських вченихекономістів: Т. Михайлова [13], В. Швеця [14] та інших. Крім того, під час проведення дослідження постала низка питань, розгляд яких формує цілі роботи.

Постановка завдання. Метою статті є дослідження, порівняльний аналіз та визначення особливостей фінансових звітів різних країн світу, порівняння принципів групування та відображення статей у балансі за міжнародними i національними стандартами, а також детермінація змін, що виникли у формі №1 «Баланс» при переході до НП(С)БО.

Методологія. Теоретико-методологічну основу дослідження складають наукові праці провідних вчених-обліковців 3 питань адаптації національної системи бухгалтерського обліку до міжнародної практики. У процесі написання статті було застосовано методи порівняння та узагальнення, метод аналізу фінансових звітів й статистичних даних.

Інформаційну базу дослідження становлять нормативні та законодавчі акти, стандарти, статистичні матеріали.

Результати дослідження. Для проведення порівняльного аналізу фінансових звітів різних країн світу взято за основу одну з форм фінансової звітності - бухгалтерський баланс.

У всіх країнах бухгалтерський баланс підприємства $\epsilon$ основним документом фінансової звітності, що являє собою головне джерело інформації про фінансово-майновий стан підприємства для зовнішніх i внутрішніх користувачів. Його основу у більшості країн складає головне балансове рівняння, що відображає взаємозв'язок та рівність між активами та пасивами.

Деякі країни, зокрема країни англо-американської системи обліку: США, Велика Британія, Канада, Нідерланди, Австралія, не мають закріпленої 
форми балансу і відображають комерційний стан підприємств, користуючись принципом повноти розкриття інформації про господарську діяльність [1].

Відмінностями у побудові бухгалтерського балансу в іноземних країнах вважають форму розташування активу та пасиву - вертикальна чи горизонтальна, а також принцип групування статей. Балансове розміщення статей може мати різні варіанти. Горизонтальна форма балансу використовується в Україні, Франції, Бельгії, Німеччині, Росії, Португалії, США, Італії, де актив відображається ліворуч, а пасив - праворуч. У Великій Британії традиційним $є$ зворотне розміщення, тому статті балансу наводяться послідовно одна за одною. Існують країни, де використовуються або вертикальна, або горизонтальна форми балансу, з законодавчим закріпленням обох, до прикладу: така ситуація у Нідерландах [1].

Радою 3 міжнародних стандартів бухгалтерського обліку (International Accounting Standard Board (IASB)), що розташована у Лондоні, затверджено Міжнародні стандарти фінансової звітності (МСФЗ), які характеризуються як стандарти, що грунтуються на принципах. Тобто стандартизація МСФЗ не ставить метою деталізацію всіх процедур та механізмів бухгалтерського фінансового обліку, не визначає форму балансу, але містить вимоги до розкриття статей активів, власного капіталу і зобов'язань. Зокрема, МСБО 1 «Подання фінансових звітів» визначає, що у балансі обов'язково повинні бути відображені наступні статті: нематеріальні активи; основні засоби; інвестиційна нерухомість; інвестиції, що обліковуються за методом участі в капіталі; біологічні активи; грошові кошти та їх еквіваленти; запаси; дебіторська заборгованість; інші фінансові активи; кредиторська заборгованість; забезпечення; інші фінансові зобов'язання; капітал; резерви; відстрочені податкові зобов'язання і відстрочені податкові активи [2].

У США існують організації, які формують національний облік i звітність. GAAP (Generally Accepted Accounting Principles) - це система бухгалтерських стандартів і процедур, яка визначається як стандарти, що грунтуються на правилах, і має побудову за принципом ієрархії, містить велику кількість документів, які розробляються державними органами (Securities and Exchange Commission - SEC, Government Accounting Standards Board - GASB) і професійними бухгалтерськими організаціями (AICPA, FASB, NAA, AAA, IMA). Кожна з них додає свій внесок в систему обліку США.

Оцінка статей балансу здійснюється відповідно до прийнятих у країні стандартів. Тому, розкриття реального фінансового стану підприємства залежить саме від достовірної і правильної оцінки. У табл. 1 наведені деякі відмінності щодо оцінки статей балансу згідно з вимогами загальноприйнятих принципів бухгалтерського обліку США (GAAP) і міжнародних стандартів фінансової звітності (IFRS). 
Оцінка статей балансу згідно з вимогами GAAP та IFRS

\begin{tabular}{|c|c|c|c|}
\hline $\begin{array}{l}\text { № } \\
3 / \text { II }\end{array}$ & $\begin{array}{l}\text { Назва статті } \\
\text { балансу }\end{array}$ & Оцінка за GAAP & Оцінка за МСФ3 (IFRS) \\
\hline 1. & $\begin{array}{l}\text { Нематеріальні } \\
\text { активи і основні } \\
\text { засоби }\end{array}$ & За залишковою вартістю & За залишковою вартістю \\
\hline 2. & $\begin{array}{l}\text { Довгострокові } \\
\text { інвестиції }\end{array}$ & $\begin{array}{l}\text { 1) за собівартістю; } \\
\text { 2) за переоціненою вартістю; } \\
\text { 3) за найменшою оцінкою }\end{array}$ & $\begin{array}{l}\text { 1) метод участі в капіталі; } \\
\text { 2) метод консолідації; } \\
\text { 3) за найменшою оцінкою }\end{array}$ \\
\hline 3. & Поточні інвестиції & $\begin{array}{l}\text { 1) за ринковою вартістю; } \\
\text { 2) за найменшою оцінкою }\end{array}$ & $\begin{array}{l}\text { 1) за собівартістю; } \\
\text { 2) за вартістю, що } \\
\text { амортизується; } \\
\text { 3) за ринковою вартістю }\end{array}$ \\
\hline 4. & Запаси & $\begin{array}{lr}\text { За меншою } & \text { двох оцінок: } \\
\text { первісною } & \text { (фактичною) } \\
\text { вартістю або ринковою ціною }\end{array}$ & 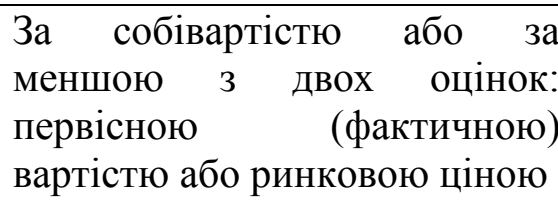 \\
\hline 5 . & $\begin{array}{l}\text { Дебіторська } \\
\text { заборгованість }\end{array}$ & $\begin{array}{l}\text { За чистою реалізаційною } \\
\text { вартістю }\end{array}$ & $\begin{array}{l}\text { За чистою реалізаційною } \\
\text { вартістю }\end{array}$ \\
\hline 6. & Грошові кошти & За фактичною вартістю & За фактичною вартістю \\
\hline 7. & $\begin{array}{l}\text { Короткострокові } \\
\text { зобов'язання }\end{array}$ & За фактичною вартістю & За фактичною вартістю \\
\hline 8. & $\begin{array}{l}\text { Довгострокові } \\
\text { зобов'язання }\end{array}$ & $\begin{array}{l}\text { 1) за фактичною вартістю; } \\
\text { 2) за приведеною вартістю }\end{array}$ & $\begin{array}{l}\text { 1) за фактичною вартістю; } \\
\text { 2) за приведеною вартістю }\end{array}$ \\
\hline
\end{tabular}

Джерело: систематизовано на основі [2, 3]

Застосування технології бухгалтерського обліку включає в себе декілька етапів. У США використовується сім основних типів рахунків, які в свою чергу поділяються на три категорії: постійні рахунки (активи, пасиви, капітал акціонерів), тимчасові рахунки (рахунки прибутків і збитків), транзитні рахунки (доходи і витрати) [3]. Для наочного відображення пропонуємо зразок балансу американської компанії Walmart (табл.2), яка за даними минулого року визнана найприбутковішою фірмою Штатів. 
Зразок балансу американської компанії Walmart

\begin{tabular}{|c|c|c|}
\hline & Початок періоду & Кінець періоду \\
\hline 1 & 2 & 3 \\
\hline \multicolumn{3}{|l|}{ Оборотні активи } \\
\hline Грошові кошти та їх еквіваленти & $8,705,000$ & $9,135,000$ \\
\hline \multicolumn{3}{|l|}{ Короткострокові інвестиції } \\
\hline Чиста заборгованість & $5,624,000$ & $6,778,000$ \\
\hline Інвентар & $44,469,000$ & $45,141,000$ \\
\hline Інші оборотні активи & $1,441,000$ & $2,224,000$ \\
\hline Разом оборотні активи & $60,239,000$ & $63,278,000$ \\
\hline \multicolumn{3}{|l|}{ Довгострокові фінансові вкладення } \\
\hline Машини та обладнання нерухомості & $116,516,000$ & $116,655,000$ \\
\hline Гудвіл & $16,695,000$ & $18,102,000$ \\
\hline \multicolumn{3}{|l|}{ Нематеріальні активи } \\
\hline \multicolumn{3}{|l|}{ Накопичена амортизація } \\
\hline Інші активи & $6,131,000$ & $5,455,000$ \\
\hline \multicolumn{3}{|l|}{$\begin{array}{l}\text { Витрати майбутніх періодів } \\
\text { довгострокових активів }\end{array}$} \\
\hline Сукупні активи & $199,581,000$ & $203,490,000$ \\
\hline \multicolumn{3}{|l|}{ Поточні зобов'язання } \\
\hline Рахунки кредиторів & 58615000 & 58583000 \\
\hline $\begin{array}{l}\text { Короткострокові/довгострокові поточні } \\
\text { борги }\end{array}$ & 6004000 & 6670000 \\
\hline \multicolumn{3}{|l|}{ Інші поточні зобов'язання } \\
\hline Разом поточні зобов'язання & 64619000 & 65253000 \\
\hline Довгостроковий борг & 44030000 & 43495000 \\
\hline \multicolumn{3}{|l|}{ Інші пасиви } \\
\hline Витрати майбутніх періодів & 7321000 & 8805000 \\
\hline Частка меншості & 3065000 & 4543000 \\
\hline \multicolumn{3}{|l|}{ Негативний гудвіл } \\
\hline Загальна сума зобов'язань & 119035000 & 122096000 \\
\hline \multicolumn{3}{|l|}{ Акціонерний капітал } \\
\hline \multicolumn{3}{|l|}{ Різні акції } \\
\hline \multicolumn{3}{|l|}{ Привілейовані акції } \\
\hline Звичайні акції & 317000 & 323000 \\
\hline Нерозподілений чистий прибуток & 90021000 & 85777000 \\
\hline \multicolumn{3}{|l|}{ Казначейський квиток } \\
\hline Надлишки капіталу & 1805000 & 2462000 \\
\hline Інший акціонерний капітал & -11597000 & -7168000 \\
\hline Сумарний акціонерний капітал & 80546000 & 81394000 \\
\hline Чисті матеріальні активи & 63851000 & 63292000 \\
\hline
\end{tabular}

Джерело: [4] 
У галузях народного господарства i торгово-промислових палатах Німеччини використовують план рахунків у вигляді класифікованого переліку i номенклатури рахунків. Допускається заміна їх назв на номери. Номенклатура рахунків у цій країні має десяткову систему - складається 310 розділів, 10 груп за кожним розділом, 10 субрахунків за кожним рахунком [5].

В іспанському законодавстві передбачено ведення бухгалтерського обліку за повною або скороченою формою звітності. Скорочений баланс включає інформацію, поділену на два розділи: актив і пасив. У активній частині балансу висвітлюється інформація про обсяг капіталу (основного та оборотного); витрати на попередню оплату короткострокових зобов'язань та інше. Пасив скороченого балансу показує суму власного капіталу, прибутку, резерву на непередбачені ситуації та платежі, суму довгострокових зобов'язань організації [6].

У бухгалтерському обліку Польщі використовують Промислову номенклатуру рахунків, затверджену законодавством. Законом також передбачено створення власного додаткового плану рахунків будь-яким підприємством. Ще один варіант ведення бухгалтерського обліку передбачає застосування планів рахунків, який розробляє Комісія 3 цінних паперів та Міністерство фінансів. У балансі подається наступна інформація про власний капітал: засновницький капітал, належні до сплати внески до власного капіталу, капітал запасний, капітал резервний, залишковий резервний капітал, нерозподілений фінансовий результат поточного i минулих років, відрахування та покриття від фінансового результату поточного оборотного року [7].

Відсутня загальноприйнята форма балансу у Нідерландах та у Швейцарі. Законодавство щодо бухгалтерського обліку не забороняє використання обох форм запису балансу (вертикальної і горизонтальної). Відсутній чітко визначений порядок класифікації статей балансу [1]. Так, оборотні засоби і поточна кредиторська заборгованість можуть бути подані як до, так і після основних засобів і капіталу. Проте законом визначено загальну структуру балансу. Кодекс зобов'язань виділяє основні чотири розділи: основні та оборотні засоби, кредиторську заборгованість та капітал.

Своєрідними в плані формування бухгалтерського балансу є Об'єднані Арабські Емірати. Підприємство країни звільняється від усіх податків, якщо

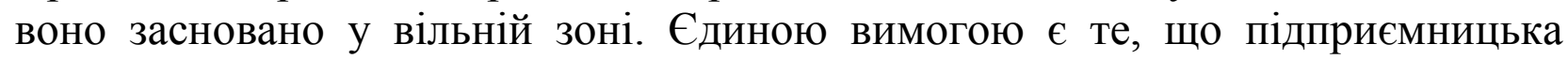
діяльність і управління компанією мають здійснюватися за межами країни, а в OAE компанія повинна мати зареєстрований офіс і вести бухгалтерський облік. Тим не менше, немає необхідності здавати бухгалтерський баланс. Мінімальний статутний капітал не встановлений, зазвичай його розмір становить 10000 дирхамів ОАЕ (близько 63500 грн). Учасник і офіційний представник не обов'язково повинні бути мешканцями ОАЕ [1]. 
Фінансові звіти різних країн відрізняються також за критеріями групування статей у балансі. Економічний зміст виступає принципом групування в італійській і німецькій бухгалтерських звітностях.

Низка країн групують статті у балансі за ступенем ліквідності. У Франції, Німеччині, Україні, Молдові, Росії, де основою національних стандартів є Міжнародні стандарти фінансової звітності, статті розміщуються за ступенем зростання ліквідності, а в Естонії та країнах англо-американської облікової системи - за ступенем спадання ліквідності. Цікавим є групування основних компонентів балансової звітності у США, які подаються наступним чином: активна частина за спадом ліквідності; зобов'язання - за строками їх списання; власний капітал - за постійністю (першими вказуються статті, на які зміни мають найменший вплив) [1].

Усі рядки португальського балансу мають відповідний двозначний чи тризначний номер рахунку бухгалтерського обліку. Дані за необоротними активами мають 3 колонки: первісна вартість, нарахована амортизація, залишкова вартість.

Дослідженням 3'ясовано, що країни з єдиним загальнообов'язковим планом рахунків мають і загальноприйняту форму балансів. А підприємства країн з правом розробляти власний план рахунків, мають і довільну форму балансу. У цьому випадку державне законодавство регламентує тільки базовий інформаційний перелік, який повинен містити бухгалтерський баланс будь-якого підприємства.

Адресна частина балансу, що містить найменування фірми, іiі юридичний статус й дату складання, майже не відрізняється у різних країнах. Варто акцентувати увагу, що дата складання фінансової звітності може бути будь-якою, з єдиною вимогою постійності обраної дати. Для більшості країн це останній день звітного періоду (місяця, кварталу, року).

За наведеним аналізом відмінностей між національними і міжнародними обліковими стандартами ідентифіковано розбіжності у формі балансу, поділу статей на поточні та непоточні активи і зобов'язання, ступені детальності інформації, приведеної у звіті (табл. 3).

Однак, відмінності у формуванні балансу наявні не тільки для різних країн та національних чи міжнародних стандартів, а й для вітчизняних положень. 3 переходом до складання фінансової звітності за національним положенням (стандартом) бухгалтерського обліку внесено деякі зміни, доповнення або спрощення. До прикладу, в НП(С)БО зазначено, що малі підприємства та представництва іноземних підприємств, що застосовують національні стандарти, можуть використовувати скорочені форми балансів. Також, передбачено право не відображати статті, що не містять інформації, яка потребує розкриття (але таке право не діє, якщо ця інформація мала місце у минулому звітному періоді), а також додавати статті (з оригінальною назвою 
і кодом рядка, які входять до списку додаткових статей фінансової звітності) у випадку суттєвості інформації і можливості ії достовірного визначення [8]. А за П(С)БО: у рядках статей, де відсутні дані, ставився прочерк.

Положенням (стандартом) бухгалтерського обліку керуються у своїй господарській діяльності юридичні особи різних форм власності, однак підприємства державної форми власності, на сьогодні, складають фінансову звітність за міжнародними стандартами (МСФЗ). Згідно НП(С)БО, правом використовувати міжнародні стандарти наділені ще й ті підприємства, які закріпили таке рішення у своїй обліковій політиці за власним бажанням (але це не стосується тих малих і середніх підприємств, що не входять до сфери дії міжнародних стандартів фінансової звітності).

Таблиия 3

Розбіжності у методиках формування балансу згідно НП(с)БО та МСФ3

\begin{tabular}{|c|c|c|}
\hline Критерій & МСФ3 & НП(С)БО \\
\hline 1 & 2 & 3 \\
\hline Побудова & $\begin{array}{l}\text { Не регламентовано; } \\
\text { наведено приблизний } \\
\text { перелік статей балансу. }\end{array}$ & $\begin{array}{c}\text { Регламентована - в активі } \\
\text { розкривається інформація } \\
\text { щодо необоротних активів, } \\
\text { оборотних активів, витрат } \\
\text { майбутніх періодів; у } \\
\text { пасиві - власного капіталу, } \\
\text { забезпечення виплат і } \\
\text { платежів, довгострокових } \\
\text { та поточних зобов'язань, } \\
\text { доходів майбутніх періодів. }\end{array}$ \\
\hline $\begin{array}{c}\text { Порядок викладення } \\
\text { інформації }\end{array}$ & $\begin{array}{c}\text { Передбачається } \\
\text { розмежування активів і } \\
\text { зобов'язань на поточні і } \\
\text { непоточні, за винятком } \\
\text { випадків, коли подання } \\
\text { інформації у балансі } \\
\text { базується на ліквідності. }\end{array}$ & $\begin{array}{c}\text { Інформація щодо активів } \\
\text { розкривається у порядку } \\
\text { зростаючої ліквідності, } \\
\text { щодо зобов'язань - у } \\
\text { порядку черговості іх } \\
\text { погашення. }\end{array}$ \\
\hline $\begin{array}{c}\text { Можливість зміни складу } \\
\text { статей }\end{array}$ & $\begin{array}{c}\text { Передбачено у разі } \\
\text { необхідності розкриття } \\
\text { суттєвої інформації згідно з } \\
\text { нормами інших стандартів, } \\
\text { або з метою забезпечення } \\
\text { достовірності та } \\
\text { правдивості інформації про } \\
\text { активи, зобов'язання і } \\
\text { капітал. }\end{array}$ & $\begin{array}{l}\text { Не передбачено. Додаткові } \\
\text { рядки вводять для } \\
\text { розкриття інформації щодо } \\
\text { інвестиційної нерухомості, } \\
\text { необоротних активів, } \\
\text { зобов'язань, пов'язаних з } \\
\text { необоротними активами. }\end{array}$ \\
\hline
\end{tabular}


Продовження таблиці 3

\begin{tabular}{|c|c|c|}
\hline $\mathbf{1}$ & 2 & 3 \\
\hline $\begin{array}{c}\text { Розкриття інформації про } \\
\text { фінансові активи }\end{array}$ & $\begin{array}{c}\text { Інформацію щодо } \\
\text { фінансових активів слід } \\
\text { розкривати окремо. }\end{array}$ & $\begin{array}{c}\text { Окремих рядків не } \\
\text { передбачено, фінансові } \\
\text { активи можуть } \\
\text { поєднуватися з } \\
\text { нефінансовими, наприклад, } \\
\text { інша дебіторська } \\
\text { заборгованість. }\end{array}$ \\
\hline Зміст статей & $\begin{array}{c}\text { Багатоваріантність методів } \\
\text { обліку довготермінових } \\
\text { фінансових інвестицій. } \\
\text { Передбачено розкриття в } \\
\text { окремій статті інформації } \\
\text { щодо непоточних активів, } \\
\text { утримуваних для продажу. } \\
\text { Передбачено розкриття } \\
\text { інформації щодо } \\
\text { результатів переоцінки } \\
\text { поточних фінансових } \\
\text { інвестицій, врахованих за } \\
\text { справедливою вартістю і } \\
\text { призначених для продажу у } \\
\text { складі іншого додаткового } \\
\text { капіталу. }\end{array}$ & $\begin{array}{c}\text { Передбачається окрема } \\
\text { стаття «Незавершене } \\
\text { будівництво». } \\
\text { Довготермінові фінансові } \\
\text { інвестиції обліковуються за } \\
\text { методом участі в капіталі. } \\
\text { У статті «Інший додатковий } \\
\text { капітал» відображається } \\
\text { сума дооцінки необоротних } \\
\text { активів, вартісних } \\
\text { необоротних активів, } \\
\text { безкоштовно отриманих } \\
\text { підприємством від інших } \\
\text { юридичних або фізичних } \\
\text { осіб. }\end{array}$ \\
\hline
\end{tabular}

Джерело: систематизовано на основі [2, 8]

У П(С)БО передбачено, що економічні показники діяльності філій, представництв, відділень та інших відокремлених підрозділів підприємства включаються до загального балансу. НП(С)БО не виключає складання такими суб'єктами господарської діяльності окремого балансу. При його створенні первинні дані про всі господарські операції вносяться у спеціально відкриті регістри бухгалтерського обліку (важливо, що у загальному балансі підприємства, складеного з урахуванням показників окремих балансів, не відображаються взаємні зобов'язання у рівній сумі) [8].

Також, необхідно зазначити відсутність у балансі, за НП(С)БО, деяких рядків, а саме: залишкова вартість нематеріальних активів, основних засобів та довгострокових біологічних активів; чиста реалізаційна вартість дебіторської заборгованості та резерв сумнівних боргів; грошові кошти в іноземній валюті; пайовий капітал; інший додатковий капітал; відстрочені податкові зобов'язання; витрати і доходи майбутніх періодів 3 окремих розділів перейшли у розділ 2 (активу) «Оборотні активи» та розділ 3 (пасиву) «Поточні зобов'язання і забезпечення» відповідно та інші. У балансі за НП(С)БО, на відміну від П(С)БО, наявний 3 розділ активу «Необоротні 
активи, утримувані для продажу, та групи вибуття» (відображається інформація про необоротні активи, для яких: економічні вигоди очікується отримати від їх продажу, а не від їх використання за призначенням; вони готові до продажу; умови їх продажу відповідають звичайним умовам продажу для подібних активів; здійснення їх продажу має високу ймовірність, якщо адміністрація підприємства розробила план або контракт про продаж, а також здійснюється їх пропозиція на ринку за ціною справедливої вартості), а також 4 розділ пасиву - «Зобов'язання, пов'язані з необоротними активами, утримуваними для продажу, та групами вибуття» [8].

Висновки. Теоретичним надбанням проведеного дослідження є те, що виявлено основні відмінності в засадах формування звітів про фінансовий стан суб'єктів господарювання різних країн світу. Наукова новизна полягає у проведенні порівняльного аналізу фінансових балансів підприємств різних країн згідно вимог міжнародних стандартів фінансової звітності (МСФ3), загальноприйнятих принципів обліку США (GAAP) та національного положення (стандарту) бухгалтерського обліку (НП(С)БО). Виявлено основні відмінності в засадах формування балансів, а саме: за формою (вертикальні і горизонтальні); за ступенем ліквідністю статей - в порядку іiі зниження або зростання (США має унікальну систему групування статей); самостійність підприємств деяких країн у обранні критеріїв групування і форми розміщення статей. Ідентифіковано розбіжності методики формування статей балансу згідно вимог НП(С)БО та МСФЗ. Аналіз методики складання балансів показав, що міжнародні стандарти є більш гнучкими, не містять регламентів за побудовою балансу, групують статті за критерієм поточності (НП(С)БО - за критерієм ліквідності), передбачають можливість зміни складу статей та відокремлене розкриття фінансових активів, на відміну від вимог НП(С)БО. Зазначено, що запозичення закордонного досвіду облікової системи сприятиме створенню дієвого механізму для прийняття управлінських рішень, спрямованих на швидке орієнтування суб'єктів господарювання в системі сучасних інтеграційних процесів.

Отже, перспективою подальшого дослідження у визначеному напрямку має стати поглиблений аналіз повного складу фінансової звітності підприємств та організацій різних країн світу, а також, вивчення зарубіжного досвіду щодо обліку й звітності для максимально можливої гармонізації різноманітних стандартів бухгалтерського обліку та облікових політик країн.

\section{Література:}

1. Руда I. О. Міжнародна практика складання та подання балансу/ I. О. Руда, Л. В. Мельянкова // Економічні науки. Сер. : Облік і фінанси. - 2013. - Вип.10(4). - С. 208-212.

2. Міжнародні стандарти фінансової звітності (IFRS) [Електронний ресурс] / Назва 3 титульного екрану - Режим доступу: zakon.rada.gov.ua/laws/show/929_010 
3. Особливості облікових систем в США [Електронний ресурс] / Назва 3 титульного екрану - Режим доступу: http://www.dsbrickworks.com/mzhnarodnij-oblk-taaudit/175-osoblivost-oblkovix-sistem-v-ssha.html

4. Walmart Stores Inc. Balance Sheet [Електронний ресурс] / Назва з титульного екрану - Режим доступу: https://finance.yahoo.com/quote/WMT/financials?p=WMT

5. Особливості облікових систем в країнах Європи - Німеччина [Електронний ресурс] / Назва 3 титульного екрану - Режим доступу: http://www.dsbrickworks.com/mzhnarodnij-oblk-ta-audit/169-osoblivost-oblkovix-sistem-vkranax-vropi-nmechchina.html

6. Особливості облікових систем в країнах Свропи - Іспанія [Електронний ресурс] / Назва 3 титульного екрану - Режим доступу: http://www.dsbrickworks.com/mzhnarodnijoblk-ta-audit/170-osoblivost-oblkovix-sistem-v-kranax-vropi-spanya.html

7. Нормативне регулювання облікової системи Швейцарії і Польщі [Електронний ресурс] / Назва 3 титульного екрану - Режим доступу: http://allref.com.ua/uk/skachaty/Normativne_regulyuvannya_oblikovoyi_sistemi_SHveiycariyi_i_ Polshi

8. Про затвердження Національного положення (стандарту) бухгалтерського обліку 1 «Загальні вимоги до фінансової звітності» [Електронний ресурс] / Назва 3 титульного екрану - Режим доступу: http://zakon5.rada.gov.ua/laws/show/z0336-13\#n147

9. Бутинець Ф. Ф. Бухгалтерський фінансовий облік / Ф. Ф. Бутинець. - Житомир: Рута, 2009. - 912 с. - (8). - (ISBN).

10. Голов С. В. Бухгалтерський облік та фінансова звітність в Україні / С. В. Голов. - Дніпропетровськ: Баланс - Клуб, 2001. - 832 с. - (3). - (ISBN).

11. Кужельний М. В. Організація обліку / М. В. Кужельний, С. О. Левицька. - Київ: Центр учбової літератури, 2010. - 352 с. - (2). - (ISBN).

12. Сопко В. В. Концепція бухгалтерського обліку пасивів (капіталу, власності) в управлінні підприємницькою діяльністю : дис. докт. ек. наук : 08.00.09 / Сопко В. В. - Київ, 2008. - $31 \mathrm{c}$.

13. Михайлов М.В., Глумаченко А.І., Гончар В.П., Бачмат Г.А. Бухгалтерський облік (теорія): Навч.посібник/ За ред. проф. Михайлова М.Г.- К.: Центр учбової літератури, 2007-247 c.

14. Швець В. Г. Теорія бухгалтерського обліку / В. Г. Швець. - Київ: Академія, 2004. -345 c. - (3). $-($ ISBN). 